\title{
Erratum to: Conundrums of a complex vector for invasive species control: a detailed examination of the horticultural industry
}

Jennifer Drew • Neil Anderson • David Andow

Published online: 26 June 2010

(C) Springer Science+Business Media B.V. 2010

\section{Erratum to: Biol Invasions \\ DOI 10.1007/s10530-010-9689-8}

Unfortunately, In the heading section "The increasing importance of the horticultural industry pathway" the sentence "In particular, gardening has increased in popularity where average household spending for lawn and garden products reached $\$ 35.102$ million in 2007 (Butterfield 2008)." was incorrectly published.

The correct sentence is: In particular, gardening has increased in popularity where average household spending for lawn and garden products reached $\$ 35,102$ million in 2007 (Butterfield 2008).

The online version of the original article can be found under doi:10.1007/s10530-010-9689-8.

J. Drew

Department of Applied Economics, University

of Minnesota, 218G Classroom office bldg,

1,994 Buford Ave, St. Paul, MN 55108, USA

e-mail: drew0052@umn.edu

\section{N. Anderson $(\square)$}

Department of Horticultural Science, University

of Minnesota, 286 Alderman Hall, 1,970 Folwell Ave,

St. Paul, MN 55108, USA

e-mail: ander044@umn.edu

\section{Andow}

Department of Entomology, University of Minnesota,

Room 219 Hodson Hall, 1,980 Folwell Ave,

St. Paul, MN 55108, USA

e-mail:dandow@umn.edu 